\title{
Flora of Singapore precursors, 16: New records and notes on the plant diversity of Singapore
}

\author{
L.M.J. Chen ${ }^{1}$, B.E.E. Duyfjes², Ali Ibrahim¹ \& W.J.J.O. de Wilde ${ }^{2}$ \\ ${ }^{1}$ Singapore Botanic Gardens, National Parks Board, \\ 1 Cluny Road, 259569 Singapore \\ ${ }^{2}$ Naturalis Biodiversity Center, section Botany, \\ P.O. Box 9517, 2300 RA Leiden, \\ The Netherlands \\ b.dewilde-duyfjes@naturalis.nl
}

\begin{abstract}
Due to ongoing work for the Flora of Singapore, a new family record for Singapore, the Stemonaceae, with one species, Stemona curtisii Hook.f., is recorded. In addition, Ammannia crassicaulis Guill. \& Perr. in the Lythraceae is newly recorded as naturalising in Singapore. Notes on two rare species, Hernandia nymphaeifolia (C.Presl) Kubitzki in the Hernandiaceae and Securidaca philippinensis Chodat in the Polygalaceae, currently being revised for the Flora of Singapore are presented.
\end{abstract}

Keywords. Aquarium plant, aquatic plant, freshwater swamp forest, naturalised species

\section{New Records of Stemonaceae and Lythraceae}

1.Stemona curtisii Hook.f., Fl. Brit. India 6: 298 (1892). - TYPE: Peninsular Malaysia, Penang, Curtis 1522 (lectotype K [K000292133], designated here).

Perennial twiner with fasciculate tubers, plant 1-2 $\mathrm{m}$ high, glabrous, somewhat branched. Leaves alternate, seldom opposite; petiole 4-12 cm long; lamina sometimes slightly rough, (narrowly) ovate, 6-21 $\times 2.5-12.5 \mathrm{~cm}$, base (shallowly or) broadly cordate, apex acuminate, 11-17(-19)-palmately-veined. Inflorescences 1-manyflowered; peduncle 1-10(-18) cm long; bracts 6-20 mm long; pedicel 10-20 mm long. Flowers tepals narrowly triangular, 17-30×5(-7) mm; stamens 18-25 mm long, filaments c. $2 \mathrm{~mm}$ long, anthers 12-15 mm long, with narrow sterile thecal remnant up to the apex, ridge separating the thecae smooth, $1-1.5 \mathrm{~mm}$ high, petaloid outgrowth of connective gradually tapering, 6-10 mm long. Capsule 25-30 mm long, c. $15 \mathrm{~mm}$ broad, shortly beaked. Seeds 5-10, dark red, 10-15 mm long, 3-3.5 mm broad; aril finger-like lobed.

Distribution. Sri Lanka, southern Thailand, Peninsular Malaysia, and Indonesia (Lepar Archipelago near Bangka).

Ecology. Across its range found in deciduous, evergreen and secondary forest, not far from the coast, on riverbanks, near waterfalls, in thickets and scrub; on sand, limestone, and poor granitic soil; from sea level to $600 \mathrm{~m}$ altitude. 
Specimens examined. SINGAPORE: Pulau Senang: Sidek S 96, 8 Jun 1967 (SING [SING0095514]). Pulau Sentosa: Cultivated, Lua SING2016-126, 15 Jun 1016 (SING [SING0236463, SING0236464, SING0236465]); Cultivated, Leong et al. SING2016-042, 21 Feb 2016 (SING [SING0243753]).

Notes. The family Stemonaceae was not included in the various recent species lists for Singapore (Turner, 1993; Davison et al., 2008; Chong et al., 2009). In the Singapore Herbarium, however, is a collection of what is clearly a native plant of Stemona curtisii from Pulau Senang and two collections of a cultivated plant from Pulau Sentosa. We suspect that these cultivated plants originated from wild plants that were already growing on Sentosa and were replanted when the original site was redeveloped. In any event, due to the Senang plant, the species can be regarded as native in Singapore. Stemona curtisii is rare in Peninsular Malaysia and also occurs in Sri Lanka, Thailand, and Sumatra (Lepar Archipelago near Bangka) (Duyfjes, 1993; Duyfjes \& Inthachub, 2011).

2. Ammannia crassicaulis Guill. \& Perr., Fl. Seneg. Tent. 1(8): 303 (1833). - TYPE: Senegal, "Cap Verde, March 1824", Perrottet s.n. in Herb. A. Richard \& Herb. E. Drake (lectotype P [P05085493], designated by Immelman, Bothalia 21(1): 41 (1991)).

Subperennial herb, glabrous, $20-40 \mathrm{~cm}$ tall, branching at the base and rooting at the nodes to form clusters of slender roots; stems reddish, erect but somewhat decumbent at base, terete, (2-)3-6 $\mathrm{mm}$ in diameter, inside spongy or nearly hollow. Leaves opposite, sessile; lamina thinly herbaceous, 3-6.5 $\times 0.8-1.6 \mathrm{~cm}$, base long-attenuate, not or only inconspicuously widened at the insertion on the stem, apex (short-attenuate or) blunt or rounded, midrib palish below, widening towards insertion on the stem. Inflorescences peduncle 1(-3) mm long; flowers 6-8 in subumbels, composed of two condensed cymes; pedicel 3-4 mm long. Flowers 4-merous; calyx tube pale green, campanulate, 1.5-2 mm in diameter, 8-ridged, ribs dark green, those ending in auricles slightly raised, lobes bluntish, less than $0.5 \mathrm{~mm}$ long, auricles green, acutish, c. 0.5 mm long; petals pink-purple, obovate, 3-3.5 mm long; stamens 4-8, inserted near the base of the calyx tube, filaments c. $1 \mathrm{~mm}$ long, anthers yellow, just exserted; ovary subglobose, c. $1 \mathrm{~mm}$ in diameter, style c. $0.1 \mathrm{~mm}$ long, stigma minute. Capsules not strongly exceeding the calyx tube, purplish, translucent, globose, c. $2.5 \mathrm{~mm}$ in diameter, many-seeded. Seeds numerous, purplish light brown, c. $0.3 \mathrm{~mm}$ in diameter.

Distribution. Tropical \& South Africa, Madagascar (POWO, 2019).

Ecology. Humid margins on banks of de-canalised waterway, subjected to periodic flooding, on stony mud soil, solitary or among other herbs. 
[SING0277279]); Chen et al. LCMJ 2018-054, 26 Sep 2018 (SING [SING0277280]); Chen et al. LCMJ 2019-080, 11 Sep 2019 (SING [SING0277281]).

Notes. Ammannia in the Lythraceae is a widespread (sub)tropical genus of mostly annual species, mainly occurring in Africa. Only one species, Ammannia baccifera L., is known to be native or naturalised in Singapore. Recently, a plant was found that could not be readily named (Fig. 1). It turned out to be a member of what was the genus Nesaea but which has now been synonymised into Ammannia by Graham et al. (2011). It has been identified as Ammannia crassicaulis which is widespread in Africa and known as an aquarium plant. The species, obviously originating from a plant that has escaped from cultivation in Singapore, grow solitary or profusely in the BishanAng Mo Kio Park at the humid margins on the banks of a de-canalised waterway in stony muddy soil which is subject to periodic flooding.

\section{Notes on Hernandiaceae and Polygalaceae}

3. Hernandia nymphaeifolia (C.Presl) Kubitzki, Bot. Jahrb. Syst. 90: 272 (1970) (Hernandiaceae)

This widespread coastal low tree species is easily recognised by its peltate leaves. It has been planted on Pulau Ubin in the mangrove forest behind the coast, but it grows naturally close-by on the coast of Johor (Joseph Lai, pers. comm.). In the SING Herbarium it is only known from one collection of a cultivated tree from Pulau Ubin (Gwee et al. GAT 180, 21 Jan 2003, SING) but it was previously recorded from Singapore without locality in the Wallich Herbarium at Kew (Wallich s.n. [EIC 7811D], Oct 1822, K-W [K001127966]).

Apart from this old collection and the recent reintroduction, Hernandiaceae are otherwise known from Singapore only from an old collection of Illigera trifoliata (Griff.) Dunn, collected by H.N. Ridley on Bukit Timah, consisting of 6 nuts (H.N. Ridley s.n., between 1890 and 1900, SING) (see also Ridley, 1924, fig. 146).

\section{Securidaca philippinensis Chodat, Bull. Herb. Boissier 4: 233 (1896) (Polygalaceae)}

This remarkable plant, a big liana, was only recently found in the Nee Soon Freshwater Swamp Forest by a team of researchers from the National University of Singapore while inventorying the tree species of the area. In an account of the genus Xanthophyllum Roxb. (Polygalaceae) from Nee Soon, Tan et al. (2016) also noted Securidaca philippinensis as a new record for Singapore. Only two locations of this species are known thus far, the second being in the Sembawang Forest. Along with the genera Polygala L., Salomonia Lour. and Xanthophyllum, the find adds a fourth genus for Singapore. 

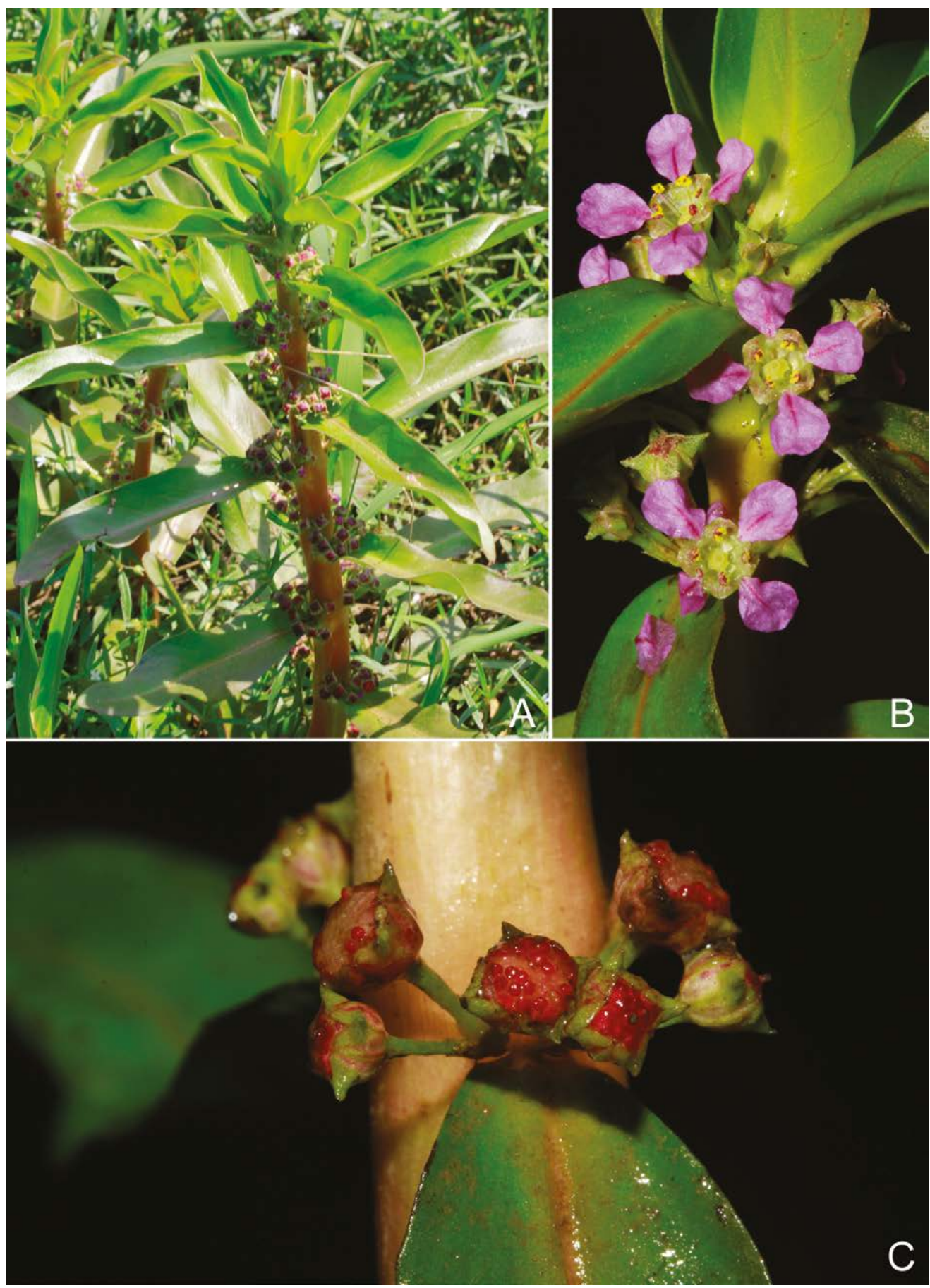

Fig. 1. Ammannia crassicaulis Guill. \& Perr. A. Plants growing along the margins of the banks of the waterway in Bishan-Ang Mo Kio Park. B. Flowers. C. Capsules. All from Chen et al. LCMJ 2018-053. (Photos: L.M.J. Chen). 

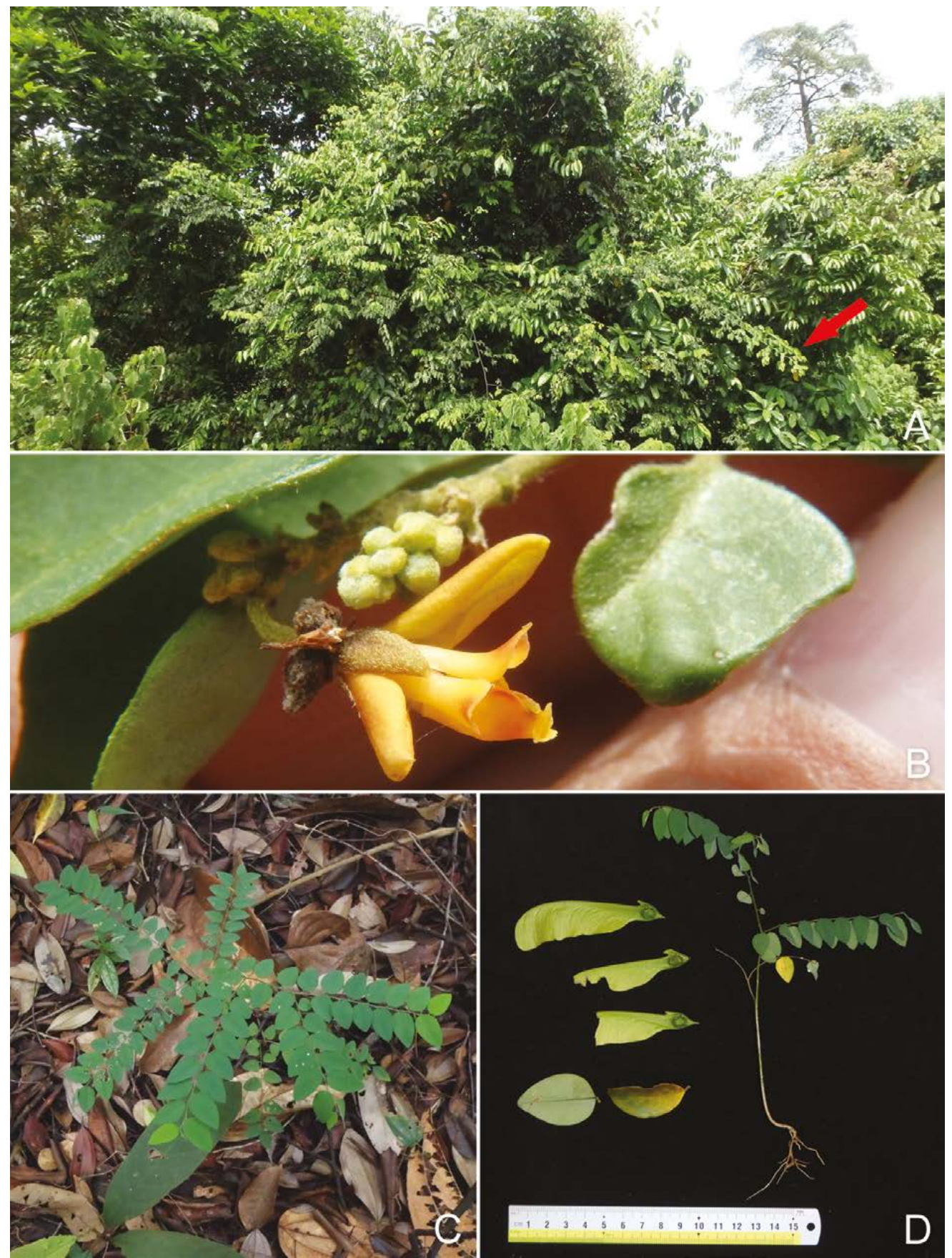

Fig. 2. Securidaca philippinensis Chodat. A. Plant in Nee Soon Range (indicated by red arrow). B. Flower. C. Seedling in Sembawang forest. D. Seeds and seedling from Sembawang (Photos: H.K. Lua). 
Securidaca L. is a widespread pantropical genus with four species in Malesia. The rather small-flowered Securidaca philippinensis was hitherto only known from Borneo and East Malaysia (van der Meijden, 1988). The plants in Sembawang Forest appear to be growing wild, are well-integrated into the vegetation, and are producing viable seed and seedlings (Fig. 2), suggesting that the species is native in Singapore rather than having been introduced.

In the SING Herbarium the first known record is from Nee Soon (Mirza SING2010-883, 15 Nov 2010, SING), with later collections from Nee Soon Firing Range (Ng SING2014-338, 11 Sep 2014, SING; Lua SING2015-035, 30 Jan 2015), Nee Soon Freshwater Swamp Forest ( Ng SING2017-724, 3 Dec 2017, SING), and at the junction of Sembawang Road and Mandai Avenue/Sembawang Forest (Lua \& Saifuddin SING2012-097, 3 Apr 2012, SING; Lua \& Saifuddin SING2013-034, 20 Feb 2013).

ACKNOWLEDGEMENTS. We would like to thank Nanthini Elamgovan, Yvonne Chee, Siti Rafeah Omer and the staff of Bishan-Ang Mo Kio Park for facilitating our work in the park, and Lua Hock Keong for field support on Securidaca and for the use of his photos.

\section{References}

Chong, K.Y., Tan, T.W. \& Corlett, R.T. (2009). A Checklist of the Total Vascular Plant Flora of Singapore: Native, Naturalised and Cultivated species. Singapore: Raffles Museum of Biodiversity Research, National University of Singapore.

Davison, G.W.H., Ng, P.K.L. \& Ho, H.C. (2008). The Singapore Red Data Book: Threatened Plants and Animals of Singapore, 2nd ed. Singapore: Nature Society.

Duyfjes, B.E.E. (1993). Stemonaceae. In: Flora Malesiana, ser. 1, Seed Plants, vol. 11, pt. 2, pp. 399-409. Leiden: Foundation Flora Malesiana.

Duyfjes, B.E.E. \& Inthachub, P. (2011). Stemonaceae. In: Flora of Thailand, vol. 11, pt. 1, pp. 74-99. Bangkok: Prachachon Co. Ltd.

Graham, S.A., Diazgranados, M. \& Barber, J.C. (2011). Relationships among the confounding genera Ammannia, Hionanthera, Nesaea and Rotala (Lythraceae). Bot. J. Linn. Soc. 166: $1-19$.

POWO (2019). Plants of the World Online. Facilitated by the Royal Botanic Gardens, Kew. http://www.plantsoftheworldonline.org/. Accessed 1 Nov. 2019.

Ridley, H.N. (1924). Hernandiaceae. In: The Flora of the Malay Peninsula, vol. 3, pp. 138140. London: L. Reeve \& Co.

Tan, S.Y., Chong, K.Y., Neo, L., Koh, C.Y., Lim, R.C.J., Loh, J.W., Ng, W.Q., Seah, W.W., Yee, A.T.K. \& Tan, H.T.W. (2016). Towards a fieldguide of the Nee Soon Swamp Forest (IV): Xanthophyllum (Polygalaceae). Nat. Singapore 9: 139-147.

Turner, I.M. (1993). The names used for Singapore plants since 1900. Gard. Bull. Singapore 45(1): 1-287.

Van der Meijden, R. (1988). Polygalaceae. In: van Steenis, C.G.G.J. \& de Wilde, W.J.J.O. (eds) Flora Malesiana, ser. 1, Seed Plants, vol. 10, pp. 455-539. Dordrecht: Kluwer. 